\title{
Ernst Wynder: Citation analysis
}

\author{
Steven D. Stellman \\ Department of Epidemiology, Mailman School of Public Health, Columbia University, New York, NY 10032, USA
}

Available online 25 September 2006

\begin{abstract}
Ernst Wynder published nearly 800 papers during his lifetime. I used the ISI Web of Science ${ }^{\circledR}$ to analyze his publications and the subsequent literature citing his work. More than half of his papers were published in just ten journals, including Cancer, Preventive Medicine (which he founded and edited), JNCI, and Cancer Research. The 87 papers in Cancer covered all of the major cancer sites including breast, colon, lung, and prostate, and many others. Twenty-five papers and one book were cited in over 200 publications. His publications included 441 co-authors from a broad range of scientific disciplines.
\end{abstract}

(C) 2006 Elsevier Inc. All rights reserved.

Keywords: Ernst Wynder; Citation analysis; Publications; Cancer epidemiology; American Health Foundation

One way to appreciate Ernst Wynder's impact on the medical and health sciences is by studying his bibliography and the citations it received over the years. Noreen Sweeney and Joanne Braley, who managed the American Health Foundation library for many years, compiled a bibliography of nearly 800 journal articles, chapters, books, and other technical writings (Hoffmann, 2006). However, the only practical way to study citing papers was to use a commercial, electronically searchable database. I used the ISI Web of Science ${ }^{\circledR}$ to generate a set of Wynder's publications and then used a Cited Reference Search to count the subsequent references to those papers. I made no attempt to eliminate self-citation (i.e., references in Wynder's own papers to his earlier publications), and I did not distinguish original research findings from reviews or invited editorials.

The ISI Web of Science ${ }^{\circledR}$ search identified 642 publications by Wynder appearing in 139 periodicals and one book; of these, 358 , or more than half, were published in ten prestigious mainline journals (Table 1). Foremost is Cancer, the American Cancer Society's flagship research journal. Wynder published nearly ninety papers in this journal over a period of more than four decades. The dominant themes were lung and breast cancer, but there were also in-depth studies of the epidemiology of cancer of the bladder, larynx, colon and rectum, stomach, ovary, prostate, pancreas, and kidney, as well as numerous experimental studies. Many of these papers were the first or most comprehensive studies ever published, especially the massive

E-mail address: sds91@columbia.edu.
1960 study of the epidemiology of breast cancer co-authored with Irwin Bross and Takeshi Hirayama (Wynder et al., 1960).

Bross and Hirayama were themselves important figures in the development of cancer epidemiology. From 1954 to 1959, Bross was head of research and design at the Sloan-Kettering Institute before its 1960 merger with Memorial Hospital for Cancer and Allied Diseases. He and Wynder (who was then a researcher at Sloan-Kettering and a staff physician at Memorial Hospital) had already co-authored seven epidemiological papers prior to the breast cancer study. By the time that paper appeared in 1960, Bross had become head of the Department of Biostatistics at Roswell Park Memorial Institute of Cancer Research in Buffalo, NY, a position he held until his retirement in 1983 . He died in 2004 having published over 300 papers and six books.

Hirayama was director of the Institute of Preventive Oncology at the National Cancer Institute in Tokyo, Japan. He organized the first large-scale prospective study of lifestyle and cancer in that country (Hirayama, 1990) and was one of the first to suggest protective effects of dietary soy against cancer (Hirayama, 1982). He published one of the earliest Japanese studies of lung cancer and cigarette smoking (Hirayama and Hamano, 1955) and his landmark 1981 paper on lung cancer in non-smoking wives of cigarette smokers helped open up the field of research on passive smoking (Hirayama, 1981). He has been called one of the "grandfathers of tobacco control in Asia" (Mackay, 2002). Wynder chose Cancer for his updated comparative study of cancer in the United States and Japan, also written with Hirayama (Wynder et al., 1991). 
Table 1

Ten journals in which Wynder published most frequently

\begin{tabular}{|c|c|c|c|}
\hline Journal & Number of papers & Percent & Years \\
\hline Cancer & 87 & 13.6 & 1956-1997 \\
\hline Preventive Medicine & 64 & 10.0 & 1974-2001 \\
\hline JNCI & 54 & 8.4 & 1957-1998 \\
\hline Cancer Research & 47 & 7.3 & $1982-1999$ \\
\hline JAMA & 28 & 4.4 & $1950-2000$ \\
\hline American Journal of Epidemiology & 27 & 4.2 & 1974-1998 \\
\hline New England Journal of Medicine & 17 & 2.6 & $1952-1992$ \\
\hline American Journal of Public Health & 12 & 1.9 & 1979-1995 \\
\hline Science & 12 & 1.9 & $1952-1980$ \\
\hline $\begin{array}{c}\text { International Journal } \\
\text { of Epidemiology }\end{array}$ & 10 & 1.6 & $1978-1995$ \\
\hline \multirow[t]{2}{*}{ All others ${ }^{\text {a, }}$, } & 284 & 44.2 & $1950-2005$ \\
\hline & 642 & 100.0 & \\
\hline
\end{tabular}

Source: ISI Web of Science ${ }^{\circledR}$.

${ }^{a}$ Includes abstracts of 17 papers presented at meetings of the American Association for Cancer Research.

${ }^{b}$ Includes a posthumous reprint of his original 1950 lung cancer study. (See Wynder and Graham, 1950).
The second most frequent journal for Wynder's publications is Preventive Medicine, which is not surprising since Wynder was its founder and Editor-in-Chief for thirty years. Besides original research reports, his papers in Preventive Medicine included editorials and an occasional feature called "A Corner of History" in which he gave thumbnail sketches of important figures such as James Lind (Wynder, 1974a) and Edward Jenner (Wynder, 1974b). It is also noteworthy that Wynder's opus included a dozen papers in Science (including our saccharin study; Wynder and Stellman, 1980) and four in Nature. Wynder published 28 papers in JAMA, including his original study of lung cancer and cigarette smoking (Wynder and Graham, 1950).

Wynder's remaining 284 publications were distributed among 129 journals ranging from Acta Medica Scandinavica to Zentralblatt Für Bakteriologie Mikrobiologie Und Hygiene Serie B-Umwelthygiene Krankenhaushygiene Arbeitshygiene Präventiv Medizin - literally A to Z. To be sure, a few papers in foreign-language journals were merely translations of papers

Table 2

Publications of Ernst Wynder cited at least 200 times in subsequent publications

\begin{tabular}{|c|c|c|}
\hline $\begin{array}{l}\text { Year of } \\
\text { publication }\end{array}$ & $\begin{array}{l}\text { No. of } \\
\text { citations }\end{array}$ & \\
\hline 1950 & 567 & $\begin{array}{l}\text { Wynder EL, Graham EA. Tobacco Smoking as a Possible Etiologic Factor in Bronchiogenic Carcinoma-A Study of } 684 \text { Proved Cases. } \\
\text { JAMA 1950;143:329-336. }\end{array}$ \\
\hline 1974 & 543 & $\begin{array}{l}\text { Narisawa T, Magadia NE, Weisburger JH, Wynder EL. Promoting Effect of Bile-Acids on Colon Carcinogenesis After Intrarectal } \\
\text { Instillation of } N \text {-Methyl- } N^{\prime} \text {-Nitro- } N \text {-Nitrosoguanidine in Rats. JNCI 1974;53:1093-1097. }\end{array}$ \\
\hline 1967 & 509 & $\begin{array}{l}\text { Wynder, E. L., and Hoffmann, D. (1967). Tobacco and Tobacco Smoke: Studies in Experimental Carcinogenesis. Academic Press, } \\
\text { New York. }\end{array}$ \\
\hline 1967 & 495 & Wynder EL, Shigematsu T. Environmental Factors of Cancer of Colon and Rectum. Cancer 1967;20:1520-1561. \\
\hline 1986 & 428 & $\begin{array}{l}\text { Howson CP, Hiyama T, Wynder EL. The Decline in Gastric-Cancer-Epidemiology of an Unplanned Triumph. Epidemiologic Reviews } \\
\text { 1986;8:1-27. }\end{array}$ \\
\hline 1957 & 410 & Wynder EL, Bross IJ, Feldman RM. A Study of the Etiological Factors in Cancer of the Mouth. Cancer 1957;10:1300-1323. \\
\hline 1977 & 396 & Wynder EL, Gori GB. Contribution of Environment to Cancer Incidence-An Epidemiologic Exercise. JNCI 1977;58:825-832. \\
\hline 1969 & 375 & $\begin{array}{l}\text { Wynder EL, Kajitani T, Ishikawa S, Dodo H, Takano A. Environmental Factors of Cancer of the Colon and Rectum. II. Japanese } \\
\text { Epidemiological Data. Cancer 1969;23:1210-1220. }\end{array}$ \\
\hline 1977 & 370 & $\begin{array}{l}\text { Reddy BS, Watanabe K, Weisburger JH, Wynder EL. Promoting Effect of Bile-Acids in Colon Carcinogenesis in Germ-free and } \\
\text { Conventional F344 Rats. Cancer Research 1977;37:3238-3242. }\end{array}$ \\
\hline 1961 & 366 & Wynder EL, Bross IJ. A Study of Etiological Factors in Cancer of Esophagus. Cancer 1961;14:389-413. \\
\hline 1973 & 358 & $\begin{array}{l}\text { Reddy BS, Wynder EL. Large-Bowel Carcinogenesis-Fecal Constituents of Populations with Diverse Incidence Rates of Colon Cancer. } \\
\text { JNCI 1973;50:1437-1442. }\end{array}$ \\
\hline 1977 & 331 & $\begin{array}{l}\text { Reddy BS, Wynder EL. Metabolic Epidemiology of Colon Cancer-Fecal Bile-Acids and Neutral Sterols in Colon Cancer Patients and } \\
\text { Patients with Adenomatous Polyps. Cancer 1977;39:2533-2539. }\end{array}$ \\
\hline 1986 & 310 & $\begin{array}{l}\text { Rose DP, Boyar AP, Wynder EL. International Comparisons of Mortality-Rates for Cancer of the Breast, Ovary, Prostate, and Colon, and } \\
\text { Per-Capita Food-Consumption. Cancer 1986;58:2363-2371. }\end{array}$ \\
\hline 1960 & 289 & Wynder EL, Bross IJ, Hirayama T. A Study of the Epidemiology of Cancer of the Breast. Cancer 1960;13:559-601. \\
\hline 1977 & 273 & Wynder EL, Stellman SD. Comparative Epidemiology of Tobacco-Related Cancers. Cancer Research 1977;37:4608-4622. \\
\hline 1971 & 262 & Wynder EL, Mabuchi K, Whitmore WF Jr. The Epidemiology of Cancer of Prostate. Cancer 1971;28:344-360. \\
\hline 1973 & 246 & Wynder EL, Mabuchi K, Maruchi N, Fortner JG. The Epidemiology of Cancer of Pancreas. JNCI 1973;50:645-667. \\
\hline 1978 & 233 & $\begin{array}{l}\text { Reddy BS, Hedges AR, Laakso K, Wynder EL. Metabolic Epidemiology of Large Bowel Cancer-Fecal Bulk and Constituents of High- } \\
\text { Risk North-American and Low-Risk Finnish Population. Cancer 1978;42:2832-2838. }\end{array}$ \\
\hline 1963 & 231 & Wynder EL, Mantel N, Onderdonk J. An Epidemiological Investigation of Cancer of Bladder. Cancer 1963;16:1388-1407. \\
\hline 1976 & 230 & $\begin{array}{l}\text { Reddy BS, Narasawa T, Weisburger JH, Wynder EL. Promoting Effect of Sodium Deoxycholate on Colon Adenocarcinomas in Germ-free } \\
\text { Rats. JNCI 1976;56:441-442. }\end{array}$ \\
\hline 1953 & 229 & Wynder EL, Graham EA, Croninger AB. Experimental Production of Carcinoma with Cigarette Tar. Cancer Research 1953;13:855-864. \\
\hline 1954 & 223 & $\begin{array}{l}\text { Wynder EL, Cornfield J, Schroff PD, Doraiswami KR. A Study of Environmental Factors in Carcinoma of the Cervix. American Journal of } \\
\text { Obstetrics and Gynecology 1954;68:1016-1052. }\end{array}$ \\
\hline 1966 & 223 & Wynder EL, Escher GC, Mantel N. An Epidemiological Investigation of Cancer of the Endometrium. Cancer 1966;19:489-520. \\
\hline 1975 & 221 & Wynder EL. The Epidemiology of Large Bowel Cancer. Cancer Research 1975;35 (11 Pt 2):3388-3394. \\
\hline 1977 & 220 & Wynder EL, Goldsmith R. Epidemiology of Bladder Cancer-A Second Look. Cancer 1977;40:1246-1268. \\
\hline 1996 & 211 & Zang EA, Wynder EL. Differences in lung cancer risk between men and women: Examination of the evidence. JNCI 1996;88:183-192. \\
\hline
\end{tabular}

Source: ISI Web of Science ${ }^{\circledR}$. 
previously published in English, but this only served to extend Wynder's international audience.

Citation analysis can give only a limited view of the impact of an individual on a field, but in Wynder's case even this view is most remarkable. A total of 25 papers and one book were cited in at least 200 subsequent publications (including self-citations of Wynder himself or other American Health Foundation investigators). These 26 publications, listed in Table 2, were cited a total of 8,549 times.

Wynder is often remembered for his strong personality and the way in which he could dominate a discussion by sheer force of intellect. Nevertheless, he could not have succeeded without an extensive network of collaborators and co-authors. The ISI Web of Science ${ }^{\circledR}$ search yielded an astonishing 441 co-authors. All of the papers in Table 2 have co-authors except one paper in a special issue of Cancer Research based on a workshop on nutrition and diet that Wynder helped organize. The papers cover a wide range of disciplines, methods (analytic epidemiology, international comparisons, metabolic studies, reviews, chemistry), and types of cancer (lung, larynx, esophagus, colon, breast, pancreas, bladder).

In the "best-seller" papers of Table 2, Wynder had 36 coauthors, seven of whom are listed in more than one publication. Bandaru Reddy, senior author of seven of those papers, was Chief of the Division of Nutritional Carcinogenesis at the American Health Foundation. For over thirty years, he has done pioneering research in chemoprevention and has published extensively on metabolism of bile acids, fecal mutagens, nonsteroidal anti-inflammatory agents, and the effect of dietary fat on the development of colon and other cancers. He is now at the School of Pharmacy, Rutgers University. Other co-authors were John Weisburger (three papers) and Irwin Bross (three papers). Weisburger was head of the National Cancer Institute Bioassay Program from 1961 until 1972, when Wynder recruited him to the American Health Foundation. As vice president and director of research at its laboratories in Valhalla, NY, Weisburger has played a major role in studies of dietary mutagens such as heterocyclic amines, as well as chemopreventive potential of lycopenes and green tea, work he continued at AHF long after his retirement in 1987. He is now at New York Medical College. Two additional papers in the list were co-authored with Nathan Mantel and one with Jerome Cornfield, both "superstar" biostatisticians.

Finally, Wynder's publication list strongly reflects his belief that advancement of public health requires the interplay and cooperation of researchers from many disciplines. Table 3 shows the co-authors with whom Wynder published the greatest number of papers. It is significant that the first three co-authors are not epidemiologists like Wynder but represent a broad range of scientific disciplines. The list is appropriately headed by Wynder's close friend and long-standing colleague Dietrich Hoffmann, who co-authored 81 papers with him between 1959 and 1999. One of the world's leading tobacco chemists, Hoffmann was associate director of the American Health Foundation and Chief of the Division of Environmental Carcinogenesis. He has made numerous contributions to our understanding of the mechanisms of tobacco carcinogenicity, and pioneered the analysis of smokeless tobacco. He is coauthor of the only book in the list of Wynder's most frequently cited publications (Wynder and Hoffmann, 1967). Second on
Table 3

Frequent co-authors of Ernst Wynder, number of publications, and dates

\begin{tabular}{lll}
\hline Author & Number of publications & Publication years \\
\hline Dietrich Hoffmann & 81 & $1959-1999$ \\
Bandaru Reddy & 45 & $1973-1997$ \\
Peter Hill & 37 & $1972-1988$ \\
Steven D. Stellman & 32 & $1977-2001$ \\
John H. Weisburger & 29 & $1975-1997$ \\
Joshua Muscat & 27 & $1991-2001$ \\
Geoffrey Kabat & 24 & $1983-1996$ \\
Randall Harris & 24 & $1988-1996$ \\
Leonard Cohen & 24 & $1974-1999$ \\
David P. Rose & 21 & $1984-1994$ \\
Edith Zang & 14 & $1989-2001$ \\
Rowan Chlebowski & 14 & $1986-1996$ \\
Christine Williams & 12 & $1976-1995$ \\
Po Chan & 12 & $1969-1981$ \\
James Hebert & 12 & $1987-1992$ \\
Evarts Graham & $12^{\text {a }}$ & $1950-1958$ \\
Alfredo Morabia & 10 & $1990-1998$ \\
Barbara Winters & 10 & $1995-1999$ \\
\hline
\end{tabular}

Source: ISI Web of Science ${ }^{\circledR}$.

${ }^{a}$ Count includes re-publication of original 1950 paper in 1985 and 2001.

the list is Bandaru Reddy (45 papers), followed by Peter Hill (37 papers) whose research interests include the influence of diet and hormones on cancer. Four of the next five co-authors are epidemiologists: myself (32 papers), Joshua Muscat (27 papers), Geoffrey Kabat (24 papers), and Randall Harris (24 papers). Scientific fields represented in the list of frequent coauthors also include biochemistry, biostatistics, oncology, nutrition science, endocrinology, and education, to name only a few.

\section{References}

Hirayama, T., 1981. Non-smoking wives of heavy smokers have a higher risk of lung cancer: a study from Japan. Br. Med. J. (Clin. Res. Ed.) 282, 183-185.

Hirayama, T., 1982. Relationship of soybean paste soup intake to gastric cancer risk. Nutr. Cancer 3, 223-233.

Hirayama, T., 1990. Life-style and mortality. In: Wahrendorf, J. (Ed.), A Large-Scale Census-Based Cohort Study in Japan. Karger, Basel, Switzerland, pp. 41-45.

Hirayama, T., Hamano, Y., 1955. The significance of smoking factor in the epidemiology of the cancer of the lung. Gann 46, 418-419 (In Japanese).

Mackay, J., 2002. Obituary: David D Yen. Tob. Control 11, 37.

Hoffmann, I., 2006. The full bibliography of Ernst Ludwig Wynder. Prev. Med. 43, 274-290. doi:10.1016/j.ypmed.2006.08.005.

Wynder, E.L., 1974a. A corner of history. James Lind's discovery of the causes of scurvy. Prev. Med. 3, 300-305.

Wynder, E.L., 1974b. A corner of history: Jenner and his smallpox vaccine. Prev. Med. 3, 173-175.

Wynder, E.L., Graham, E.A., 1950. Tobacco smoking as a possible etiologic factor in bronchiogenic carcinoma-A study of 684 proved cases. JAMA 143, 329-336.

Wynder, E.L., Hoffmann, D., 1967. Tobacco and Tobacco Smoke: Studies in Experimental Carcinogenesis. Academic Press, New York.

Wynder, E.L., Stellman, S.D., 1980. Artificial sweetener use and bladdercancer-Case-control study. Science 207, 1214-1216.

Wynder, E.L., Bross, I.J., Hirayama, T., 1960. A study of the epidemiology of cancer of the breast. Cancer 13, 559-601.

Wynder, E.L., Fujita, Y., Harris, R.E., Hirayama, T., Hiyama, T., 1991. Comparative epidemiology of cancer between the United-States and JapanA7 2nd look. Cancer 67, 746-763. 